\title{
天然記念物湿原の保全に関する研究
}

\author{
中園健文 ${ }^{1} \cdot$ 秋吉康弘 ${ }^{2} \cdot$ 稲垣仁根 $^{3} \cdot$ 小山田正幸 ${ }^{3}$
}

\section{A Study on Preservation of a Natural Treasure Marsh}

\author{
Takefumi Nakazono $^{1}$, Yasuhiro Akiyoshi ${ }^{2}$, Hitone Inagaki ${ }^{3}$ \\ and Masayuki Oyamada ${ }^{3}$
}

\begin{abstract}
Kawaminami Marsh, located in Kawaminami Town, Koyu County, Miyazaki Prefecture, is the only national natural treasure in Kyushu. However, precious marsh plants are threatened by urbanization around the marsh which is lowering the groundwater level and worsening the water quality due to the inflow of waste water. As the aim of this research is to preserve and increase the populations of plants in the marsh, groundwater level fluctuation, precipitation, water inflow into the marsh, and marsh water quality were surveyed and plants in the marsh were observed in the period of 1995 to 2001 of fiscal year. The surveys verified the very large influence of the water environment on preservation and propagation of aquatic plants in the marsh. In particular, the lowering groundwater level has caused by the increasing demand of water resources, and the input of waste water from the surrounding area has resulted in the eutrophication of the marsh water, and as a result, marsh plants were found to wither and die. To preserve marsh plants and encourage their growth in the future, the waterway traversing the marsh was backfilled. Cedar trees on the south side, evergreen trees on the north side, and waste farm products on the north side of the marsh were removed. These measures improved the ventilation of the marsh and also improved the sunlight and groundwater flow, which are essential for the growth of marsh plants. Due to these changes in the marsh environment, the number of marsh plants is increasing, indicating the gradual restoration of plants in Kawaminami Marsh. Measures in the marsh have been almost completed. In the future, waste water discharged from a nearby hospital will be redirected to the sewage system and the irrigation tank supplying water to the marsh will be dredged to remove nutritious sediment at the bottom.
\end{abstract}

Keywords: National natural treasure; Marsh; Groundwater; Water quality; Nature preservation

\section{1 まえがき}

湿原は，かつて日本の低地に広大に広がっており，環 境に忍じてさまざまな植物群落が見られていた。しか し, 都市開発により湿原は埋め立てられ, 残存する数 少ない湿原も水需要に伴う地下水位の低下, 湿原周辺 から流入する生活雑排水等による水質の悪化など湿原 植物の生育が危ぶまれている.

本研究は，九州唯一の天然記念物である宮崎県児湯 郡川南町の川南湿原 (川南湿原は, 昭和 41 年 9 月 1 日，県の文化財に指定され，昭和 49 年 6 月 11 日に は，国の天然記念物に指定されている）を調査対象地 区に定め, 湿原植物の保全・増殖を図るために, 平成 7 年度〜平成 13 年度の期間, 地下水位の変動や降水 量, 湿原の流入水と湿原水の水質の調査, 湿原内に生 息する植物の観察を行うことを目的とする（川南町教 育委員会, 1999a ; 秋吉ら, 2002 ; 秋吉ら, 2003)。近 年, 川南湿原では, 湿原周辺の都市化に伴い, 地下水 位の低下，湿原周辺から流入する生活雑排水等による 水質の悪化などによって, 天然記念物の貴重な湿原植 物が枯死寸前の状態を呈している.

そこで，川南湿原植物の生育に大きく影響を与える 水環境について, 特に, 湿原内の地下水位の変動と水

\footnotetext{
1宮崎大学農学部助手 Assistant Professor, Faculty of Agriculture, University of Miyazaki, 1-1 Gakuen Kibanadai-nishi, Miyazaki-shi, Miyazaki, 889-2192 Japan

2宮崎大学農学部教授 Professor, Faculty of Agriculture, University of Miyazaki, 1-1 Gakuen Kibanadai-nishi, Miyazakishi, Miyazaki, 889-2192 Japan

3 宮崎大学農学部助教授 Associate Professor, Faculty of Agriculture, University of Miyazaki, 1-1 Gakuen Kibanadai-nishi, Miyazaki-shi, Miyazaki, 889-2192 Japan
}

質の変動を調查し，同時に，湿原に流入する水量，す なわち，湧水量とため池に隣接する病院からの処理水 量および灌溉期の用水流量を測定し，湿原の水生植物 の保全・増殖について調査究明する。 そして，世界的 に貴重な川南の湿原植物を保全し, 今後の成長をさら に活性化させるために種々の対策を行い，湿原植物の 保全と増殖を図るための研究を行ったものである.

\section{2 調査地区概要}

本調査地区である「川南湿原植物群落」は，尾鈴山系 の麓に位置しており，隣接する病院北側のため池の周 りから国道 10 号線の間の約 $2.2 \mathrm{ha}$ の湿地帯である.川 南湿原の全景は，写真 1 に示すとおりである.

\section{3 調査研究方法}

\section{1 地下水位}

湿原地形および地下水位測点位置は図 1 に示すとおり である．湿原内の地形は平板測量から平面図を作成し， レベル測量によって $0.20 \mathrm{~m}$ 間隔の等高線を記入して 作成したものである。なお，図中のNo. は地下水位の 測定地点であり，測定地点は，No.1〜No.17 と平成 9 年に設置した No.13'とNo.14'の計 19ヶ所である。ま た, No.13'と No.14'は, 既設の No.13 と No.14から $1 \mathrm{~m}$ 離れた位置に設定している。

地下水位の測点では, 図 2 に示すような内径 $0.03 \mathrm{~m}$ の塩化ビニール管に多数の穴を開けたものを土中に埋 設した。 これは，地下水が塩化ビニール管内に自然流 入し，地下水位と塩化ビニ一ル管内の水位を同一とす る構造となっている．地下水位の測定には，テスター 


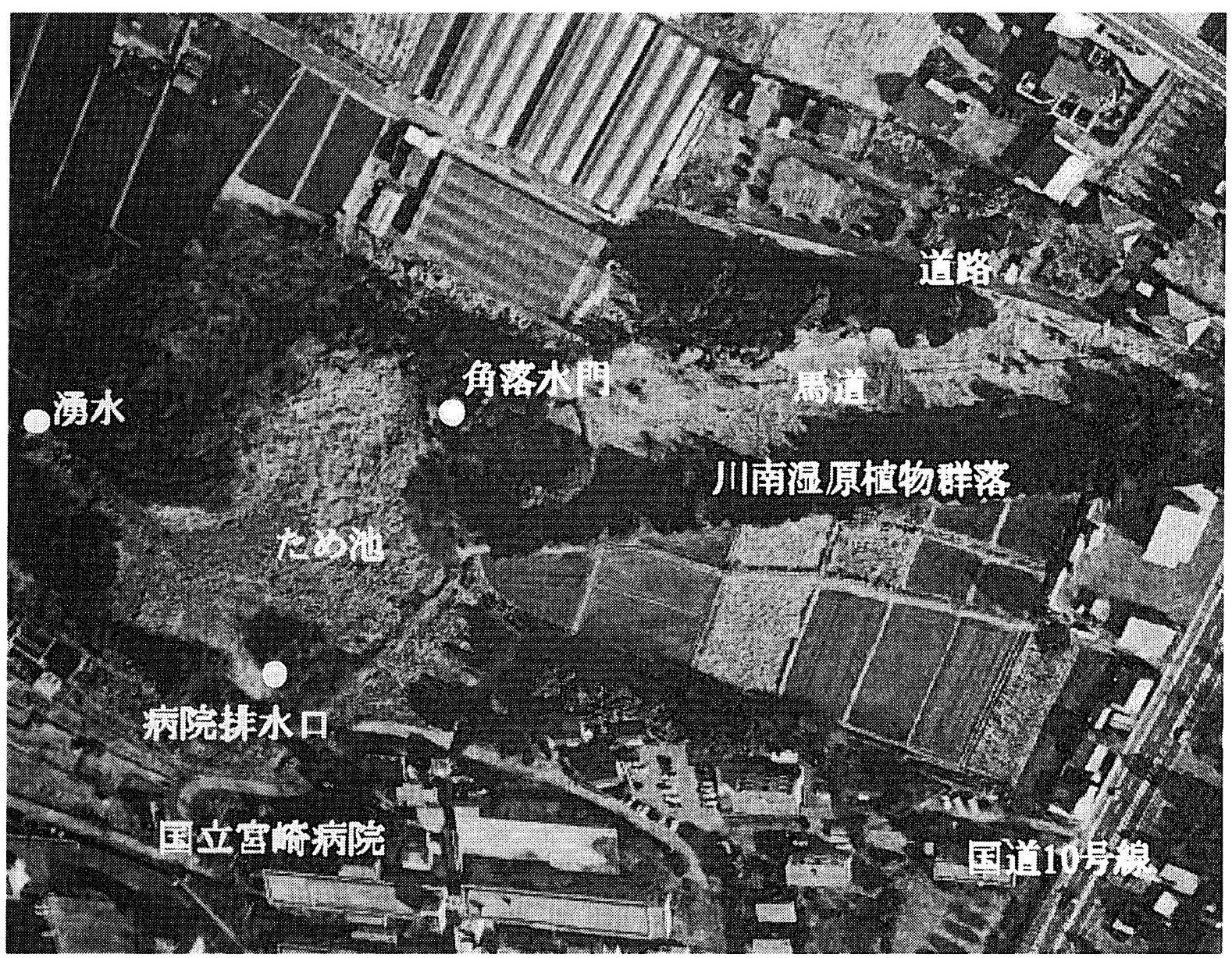

写真 1: 川南湿原植物群落全景

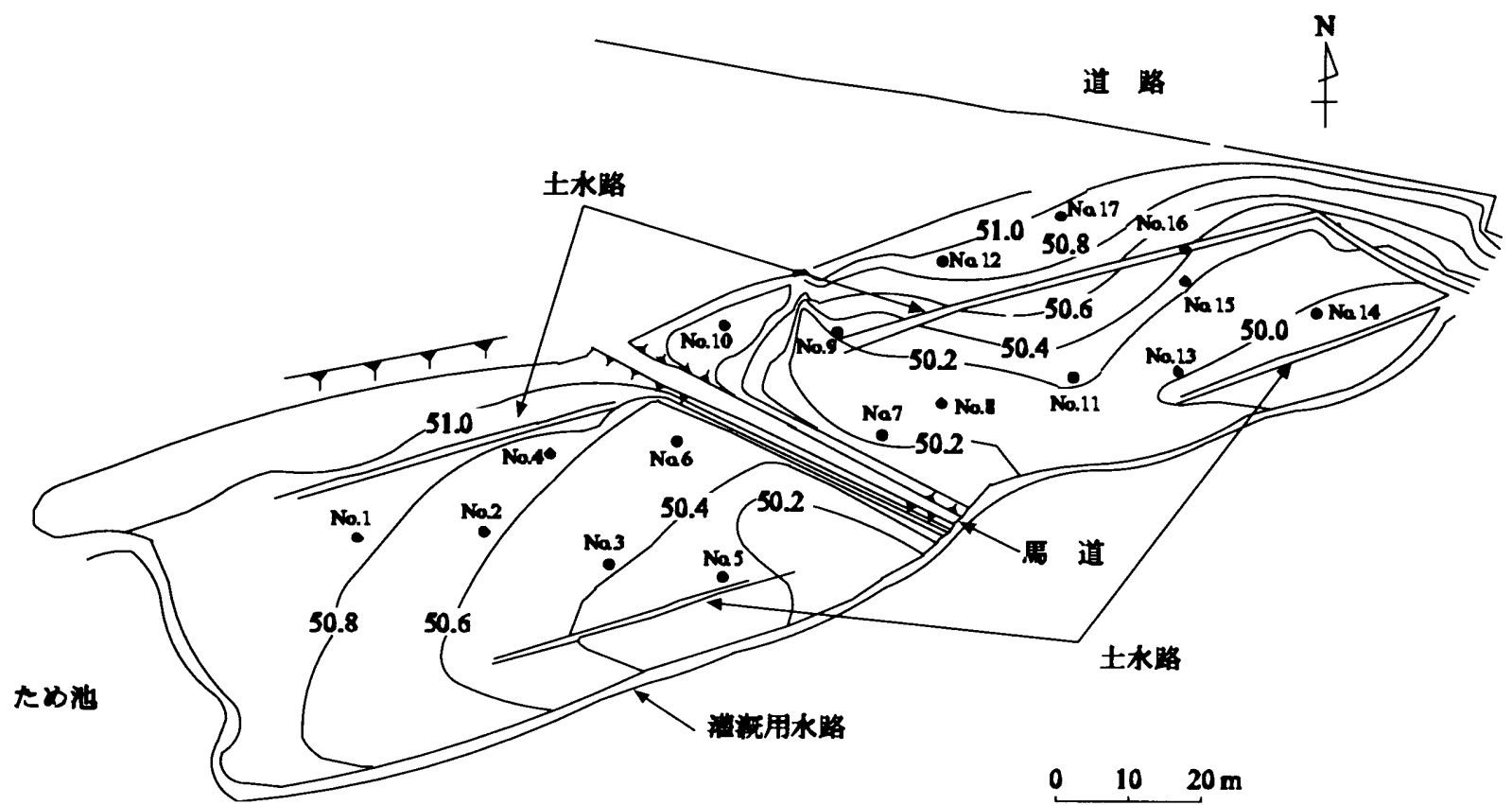

図 1: 湿原地形および地下水位測定位置 
を用い，十極と一極とが水面に到達した瞬間に針が振 れることを確認し，その時の深さを地盤高から差し引 いて，地下水位を 1 週間ごとに求めた。

また, No13 と N o13'さらに No.14 と No.14'の間 には, 深さ $0.20 \mathrm{~m}$ 程度の遮蔽板（アクリル板）を土中 に埋設し，地下水位の流動を遮断した。これは，遮蔽 板の上流側と下流側との地下水位の変動を比較し, 地 下水位の制御を実験的に行うことを目的としたもので ある。

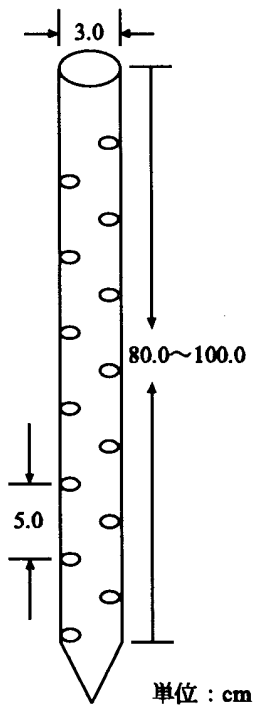

困 2: 地下水位測定装置

\section{2 水質}

湧水㧍よび病院からの処理水, 湿原への流入水および 湿原水の水質調査については毎月 1 回の割合で測定し た。調查内容は, 湿原に流入する流入水と湿原水の水 温, 水素イオン濃度 $(\mathrm{pH})$, 溶存酸素量 $(\mathrm{DO})$, ア ンモニア態窒素 $\left(\mathrm{NH}_{4}-\mathrm{N}\right)$ ，业硝酸態窒素 $\left(\mathrm{NO}_{2}-\mathrm{N}\right)$, 硝酸態窒素 $\left(\mathrm{NO}_{3}-\mathrm{N}\right)$, リン酸塩 $\left(\mathrm{PO}_{4}-\mathrm{P}\right)$ ，有機態 窒素 $(\mathrm{Org}-\mathrm{N})$, 有機態リン $(\mathrm{Org}-\mathrm{P})$, 化学的酸素要 求量 (COD), 無機態全窒素 (TIN), 全窒素 $(\mathrm{T}-\mathrm{N})$, 全リン (T-P) である.

\section{3 その他の調査項目}

地下水位と水質の他に気温, 降水量, 湿原内に生育寸 る植物の観察を行い, 湿原の水環境を考察し, 今後の 湿原の保全対策について調查研究した。さらに，湿原 内に生育する植物については，地下水位の測定と同時 に，植物の開花時期，開花場所，個体数を調査し，定 点観測の意味で植物の写真撮影を行って比較調査した.

\section{4 調查結果及び考察}

\section{1 降水量について}

本調査地区の平成 8 年〜平成 13 年までの 6 年間の調 査期間中の年間降水量は，表 1 に示すとおりである. この結果, 調査期間における最小年降水量は, 平成 8 年の $1,869.4 \mathrm{~mm}$ で, 最大年降水量は, 平成 11 年度の $3,089.9 \mathrm{~mm}$ あり, 平均年降水量は $2,409.3 \mathrm{~mm}$ であっ た。我が国の年平均降水量である $1,755.0 \mathrm{~mm}$ に比べ
るとやや大きめの降水量であるが，宮崎県の年平均降 水量である $2,400.0 \mathrm{~mm}$ とははぼ同程度である。

\section{2 地下水位について}

平成 7 年 2 月〜平成 12 年 12 月の地下水位の変動につ いて考察する。

\subsection{1 地下水流動と湿原植物増殖の関係}

湿原植物は常時湛水状態では生育が困難で, 日陰は好 まず，適度に日射量があり，風通しが良いことが生育 環境の必要条件である. 特に, 地下水が常時流れてい る状態が湿原植物成長の保全・増殖に最適である。湿原 植物の成長に対する地下水の流況は, 清浄な地下水の 流れが常時あること，かつ，地下水面が，土壌表面下 ほぼ $0.15 \sim 0.20 \mathrm{~m}$ 程度にあり，一定の地下水面を保っ ていることが必要である。

\subsection{2 平成 $7 \sim 10$ 年度}

本調査地区内での地下水の流動は, 図 3 に示すように, ほぼ地盤勾配にしたがって流下している。平成 7 年度 の調査開始時には，湿原内の表面水を排除寸ることを 目的に湿原中央部を横断するような形で幅 $0.50 \mathrm{~m}$ ，深 さ $0.40 \mathrm{~m}$ 程度の土水路が掘られていた。

しかし，土水路の吐け口がなく湛水状態を呈してい たために, 地下水の流れが少なく湿地帯の様相を示し, 水質も非常に悪い状態を呈していた。調査の結果, 図 3 に示寸ように，北西から南東への地盤の傾斜にした がう地下水の流れが土水路に流入するために，土水路 が地下水の流れを遮断し，下流への地下水の連続的な 流動を妨げていると判断した。

\subsection{3 平成 11 年度}

改善策として平成 11 年度に土水路を埋め戻した。こ の土水路の埋め戻しに際して, 他地区からの埋め戻し 土の搬入は，天然記念物としての自然の環境を壊すこ とになるので，水路周辺の土砂を利用して埋め戻しを 行った.

測点 No.4 地点の地下水位変動を図 5 に示寸が，土 水路の埋め戻しの結果, 測点 No.4 は, 夏の雨が降ら なかった時期には地下水位は低下しているが，それ以 外の時は，ほぼ常時湛水している状態が継続している. 測点 No.4 で湛水している原因は, 測点 No.4 が地形 的に傾斜面がほぼ水平に移行した個所であり，土水路 を埋めたことにより，地下水位の流れが途中で中断さ れることがなく，上流から下流へ連続して流れるよう になったためであると考えられる。 また, 测点 No.3, No.5, No.6においても, 測点 No.4 と同様な傾向が見 られ，年間の地下水位の経日変動幅も小さくなってい る. その結果, 地下水の流動状況は, 図 4 に示すよ うに，ほぼ北西から南東への地盤の傾斜にしたがって 地下水が流動していることが確認でき，その後の湿原 植物の増殖が非常に活発になった。

\subsection{4 平成 12 年度}

平成 11 年度に土水路を埋め戻したが，湿原の南側の 直径 $0.30 \sim 0.40 \mathrm{~m}$ もあるスギの高木が約 $1 \mathrm{~m}$ 間隔にそ びえており，風通しは非常に悪く，地下水の流れはあ まりない状態で，土壌面の状態も水が澱んでいる状況 であった。 
表 1: 川南湿原の年間降水量

\begin{tabular}{c|c|c|c|c|c|c}
\hline 年 度 & 平成 8 & 平成 9 & 平成 10 & 平成 11 & 平成 12 & 平成 13 \\
\hline \hline 年降水量 $(\mathrm{mm})$ & 1869.4 & 2006.7 & 2024.7 & 3089.9 & 2601.0 & 2864.5 \\
\hline
\end{tabular}

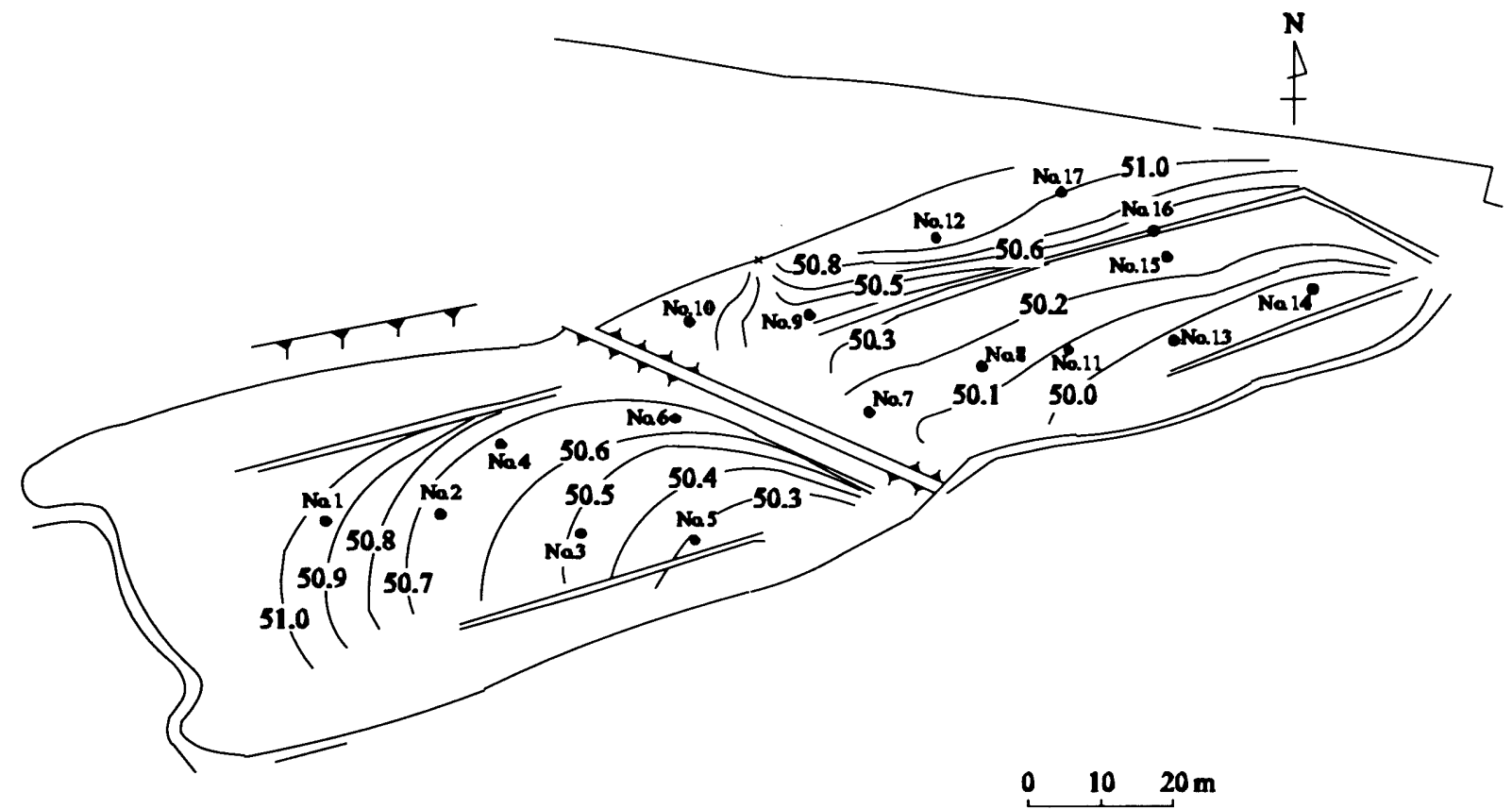

図 3: 土水路が存在する場合の地下水の流動状況

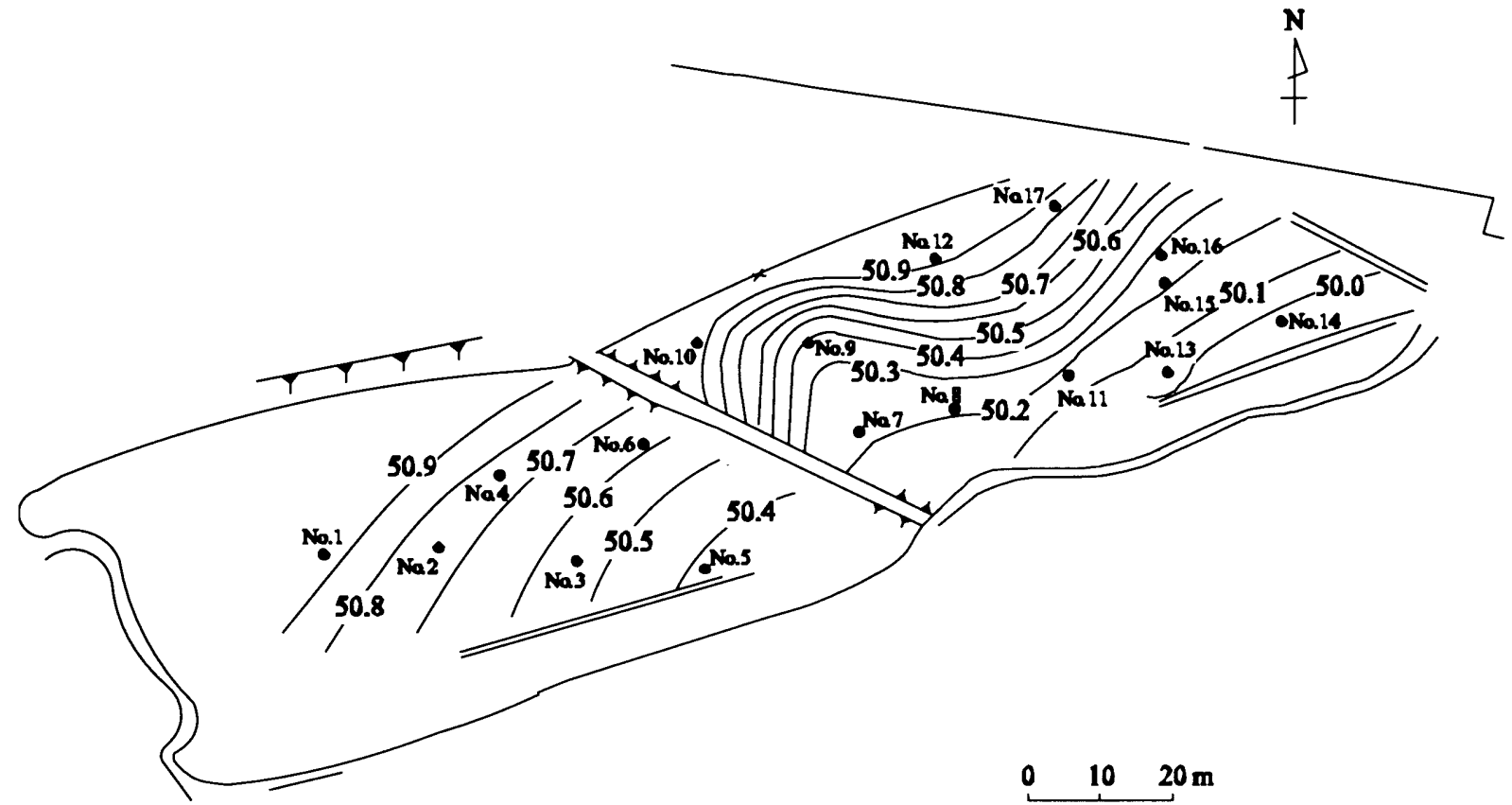

図 4: 土水路埋め戻し後の地下水の流動状況

そこで，この改善策として，平成 12 年度に湿原南 側のスギの高木を除去することとした，その結果，風 通しはよくなり，太陽が良く当るようになり，そして， 蒸発散が活発になったために, 上流からの地下水の流
動が活発になった, その結果, 測点 No.3, No.5, No.6 での湿原としての条件が良くなり, 湿原植物の生育状 況が非常に良い状態に改善されたと判断した。 


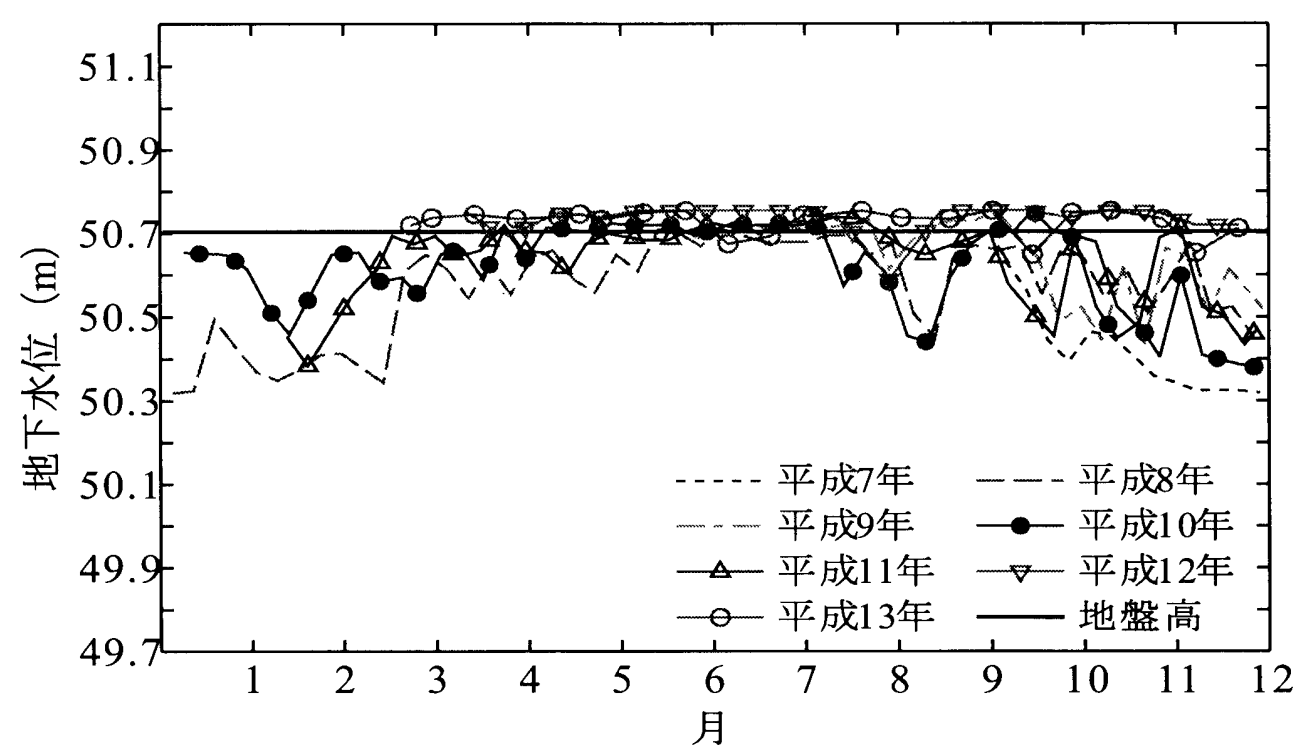

図 5: 平成 $7 \sim 13$ 年度の地下水位経日変化図（測点 No.4）

\subsection{5 地下水位と降水の関係}

本調查地区での地下水位の変動は, 降水との関連が非 常に大きく影響しており，たとえば， 6 月初旬〜 6 月 下旬の間に降水があると上昇し， 7 月初旬〜 7 月下旬 の間に降水がない時には低下している。 そして，8月 にまとまった降水があると再び上昇するという傾向を 示しているが, 10 月以降は降水の影響は小さくなっ ている.これらの原因は，夏場の水分の蒸発が多い時 期は，土壌の含水比の関係で，降水の影響も大きくな ると考えられるが，平成 12 年度のように秋口から是 天が続いた時には，土壌中の含水比が高くなり，降水 が地下水位に与える影響力は少なくなるためと推察さ れる.

地下水位の変動幅が最も大きかったのは, 測点 No.11 の平成 12 年 8 月 28 日〜 9 月 14 日の $0.44 \mathrm{~m}$ であった. これは，約 1 ヶ月間降水がなく, 8 月 28 日から $80 \mathrm{~m}$ $\mathrm{m} \sim 100 \mathrm{~mm}$ 程度の大雨が長い間続いたために，地下 水位が地表面下 $0.46 \mathrm{~m}$ まで低下していたものが急激 に上昇したためと考えられる。一方，変動幅が最も小 さかったのは, 測点 No.9 での $0.03 \mathrm{~m}$ であった。測点 No.9 は湿原内での湧水の流路にあり常時湛水状態で あるため，降水の影響をあまり受けず，変動幅が小さ くなったと考えられる。

\section{3 アクリル板設置による地下水位制御}

地下水位の制御を行うために, 平成 9 年に測点 No.13, No.14に実験的に埋設したアクリル板の影響について 考察する. 地下水位の変化は, 測点 No.13, No.13' と もにほぼ同じような地下水位変化を示しているが，ほ とんどの時期, 測点 No.13の地点よりも, 上流側の測 点No.13'の地下水位の方が高い傾向が見られた. 水 位の差は最大で, 平成 13 年 5 月 6 日の $0.10 \mathrm{~m}$, 測点 No.14では最大で $0.07 \mathrm{~m}$ であった。

この結果，アクリル板の設置による地下水位の制御 が僅かではあるが可能であることが確認された。この アクリル板を有効に使用寸ることで，地下水位の影響 を受けやすい湿原植物の保全が可能であると思われる。
これら No.13 と No.14の 2 地点には， 4 月下旬〜 5 月 下旬にはハルリンドウが，8月中旬〜 9 月中旬にはミズ ギボウシ， 10 月上旬〜 11 月下旬にはスイランが咲き 乱れ，アクリル板埋設による効果があると考えられる.

\section{4 流入水量について}

ため池への流入水には，ため池の西側に尾鈴山を背景 とする湧水と, ため池に隣接する病院の污水処理場か らの処理水がある. また, 湿原一の流入水は, ため池 から角落水門を通る流入水と湿原北側から流入する生 活雑排水がある.これに加えて, ため池下流から湿原 の入口には灌溉用水路があり, 灌溉期のみ湿原内に流 入している.

ため池の水位は，ため池末端にある角落水門によっ て, 調節が可能である. 灌溉期になると, 角落としを 設置し, ため池の水位を高め, 灌溉用水の確保を行っ ている。ほぼ毎年, 3 月中旬に角落としを設置し， 8 月上旬に除去している.

角落水門における湿原人の最大流入量は平成 11 年 8 月 2 日の約 $0.1453 \mathrm{~m}^{3} / \mathrm{s}$ であり, 最小流入量は平成 11 年 3 月 2 日の約 $0.0015 \mathrm{~m}^{3} / \mathrm{s}$, さらに平常時の流入 量は約 $0.0345 \mathrm{~m}^{3} / \mathrm{s}$ である.ため池に隣接する病院か らの排水処理場の三角ゼキ流量は約 $0.0108 \mathrm{~m}^{3} / \mathrm{s}$ でほ ぼ一定である. 湧水流量は, 流量測定装置がなく, こ れらの流量結果から推測する。病院での使用水の約 $40 \%$ を水道水に依存していることから, 処理水の内 $0.00432 \mathrm{~m}^{3} / \mathrm{s}$ は水道から新規にため池に供給された流 量である. 従って, ため池自体の平常時の湧水量は, 平常流入量から新規供給量を差し引いた約 $0.030 \mathrm{~m}^{3} / \mathrm{s}$ 程度であると考えられる。

\section{5 水質について}

湿原植物は，一般的に貧栄養で, 酸性の土壌に生育す る. そのため近年の生活雑排水の流入に伴う湿原水の 富栄養化が, 湿原にどの程度の影響を与えているかが 問題となっている. そこで, 湿原に流入する流水を採 水して，水質を1ヶ月ごとに調べた. 
湿原に流入する水は，(1)ため池の西側に尾鈴山圭背 景と寸る湧水，(2)ため池に隣接寸る病院の污水処理場 からの処理水，(3)ため池下流でかつ湿原入口での灌溉 用水（ただし，灌穊期のみ），(4湿原北側から流入す る生活雑排水の計 4 箇所である。

\subsection{1 水素イオン濃度 $(\mathrm{pH})$}

平成 8 年 11 月に $\mathrm{pH} 9.98$ の最大值が湿原内で観測され た。しかしこの高濃度は気温と水温との関倸により 突発的に高濃度になったためのものであり，湿原植物 の生育には悪影響を与えるものではない，最小值は， 平成 11 年 10 月に湧水で観測された $\mathrm{pH} 5.03$ である.

\subsection{2 全窒素 ( $\mathrm{T}-\mathrm{N})$}

最大值が平成 9 年 11 月に湧水で観測された $80.25 \mathrm{mg} / \mathrm{L}$ であり，最小值は平成 11 年 10 月の湿原内で観測され た $2.56 \mathrm{mg} / \mathrm{L}$ である. 湿原植物は，貧栄養（ $\mathrm{T}-\mathrm{N}$ 值で は $0.2 \mathrm{mg} / \mathrm{L}$ 以下）在好むので，湿原植物にとっては 好ましい水環境ではない.

\subsection{3 全リン (T-P)}

ため池に隣接寸る病院の污染処理水からの流入水の濃 度が他の水よりも濃度が高くなっている，最大值は， 平成 12 年 11 月に污染処理水で観測された $3.10 \mathrm{mg} / \mathrm{L}$ で, 最小值は平成 8 年 12 月に湿原内の水から観測さ れた $0.01 \mathrm{mg} / \mathrm{L}$ である.

\subsection{4 化学的酸素要求量 (COD)}

最大值は, 平成 11 年 11 月に污染処理水で観測された

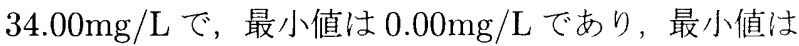
複数の箇所，時期で観測している. 水質基準として用 いられる COD 指標である湖沼の許容範囲とされてい る $8.00 \mathrm{mg} / \mathrm{L}$ に対して, 本調査地区では平時は許容基 準の $8.00 \mathrm{mg} / \mathrm{L}$ 以下の值となっている.

\subsection{5 溶存酸素 (DO)}

最大值は, 平成 10 年 12 月に湿原内の水から観測され

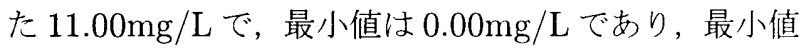
は複数の箇所, 時期で観測している. また, 平常時で は，通常の湖沼水質基準の $5.00 \mathrm{mg} / \mathrm{L}$ 程度である.

従って, 湿原内の水質状況について全般的にリン濃 度と窒素濃度が高く, 富栄養化していると推測される。 また，それらの富栄養化の原因としては，ため池に隣 接寸る病院の污水処理場と生活雑排水の湿原内一の流 入によるところが大きいと考えられる.

それでも湿原内の環境の徳化が進行しないのは，た め池内に生息する高さ $1 \mathrm{~m}$ 程度にまで成長したホテイ アオイやその他の水生植物による水質浄化作用が大き いものと推察される. 病院処理水流入口とため池の出 口にある角落とし設置部分は，ちょうどため池の対岸 に位置している。，そして，このため池面積約 1ha 内に はホテイアオイ等の水生植物が水面全体を覆っている. これらホテイアオイ等の水生植物の水質浄化能力は, 非常に大きく約 $1 / 10$ 程度にまでリンや窒素の除去が なされている.

\section{5 まとめ}

調査結果から, 湿原の水生植物の保全と増殖には, 水 環境の影響が非常に大きいことが確認された。特に, 湿原周辺での都市化に伴う地下水位の低下, 貧栄養を
好む湿原水り生活雑排水に上る富栄養化などで湿原 植物が枯死の危機にさらされていることが明らかに なった。

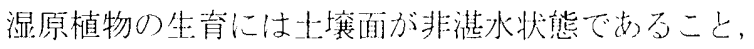
日陰は好まず，日照時間内においては日射が龸に䘕わ 礼ていること，生育場所の通気性が良好である等の翼 境条件が必要となる。特に, 清浄な地下水が常時流動 することは，根圈域への酸素の供給を增大させること になり，湿原植物成長の保全・增殖に最も筞与寸万条 件となる。たとえば，水質が悪く多少富栄養化してい ても，地下水に流れがあれば湿原植物の生青には，あ まり影響を与えない場合もある。しかし，本地区にお いて湿原植物が維持されているのは, 種々の水生植物 による水質浄化作用が大きく影響しており，たとえば， ため池内に生息するホテイアオイは高さ $1 \mathrm{~m}$ 程度にま で成長している。このように，水生植物による水質浄 化の効果は，非常に大きいことが確認できた。

そこで，以上のような調査結果を踏まえ，湿原植物 の保全と增殖について改善策とその効果についてまと める。 また, 植物群落自然環境の調査(川南町教育委 員会，1999b）による川南湿原内での湿原植物の分布 状態とその植生図の凡例老図 6 に示寸。

（i）地下水の流動を活発にするための改善策として， 平成 11 年度に湿原中央部の土水路を埋め戻した。

(ii) 平成 12 年度には, 湿原の南側に約 $1 \mathrm{~m}$ 間隔に立 ち並んだ直径 $0.30 \sim 0.40 \mathrm{~m}$ のスギの除去や北側 にある樹林地の常緑樹等の高さを押さえるため の伐採を行った。

（iii）地下水の污染をなくすために，湿原北側のメ口 ン等の廃辌された農作物の除去等を実施した。

(iv)このような対策の結果, 湿原植物の生育に重要 な因子である湿原への通気性，湿原植物の生青 に必要不可欠な太陽加の日射や地下水の流動 が以前よりもかなり改善された。

（v）地下水位制御対策として，遮蔽板（アクリル板） を僅か深さ $0.20 \mathrm{~m}$ 程度の土中への㨂入すること により，0.05〜0.10m 程度であれば地下水位の制 御が可能であることが認められた。

(vi) このような湿原の環境の変化に対して, 湿原植 物の株数が増加し, 平成 13 年度 5 月にはトキy ウ，ハルリンドウ，6月にはカキラン，コバノト ンボソウ，キンバイザサ，ミズキy (6月下何〜 7 月), 8 月にはサギソウ，ミズキボウシ，サワシロ ギク，9月にはサワヒヨドリ，マメア少ガオ，少 ワシロキク，10月にはホソバリンドウ，サワヒ ヨドリ，ヤマラッキョ，11月にはウメバチソウ， ヤマラッキョなどの草花の開花が影著になった。

(vii) ナガバノイシモチソウ，モウセンゴケ，コモウセ ンゴケ，ミミカキグサなど食虫植物も生充寸る ようになり，川南湿原の保全と增殖が少しづつ ではあるが改善され始めてきた。

以上のように，湿原内での対策は効果を発揮したが， 今後の対策としては, 水質の改善に重点を执かなけれ 


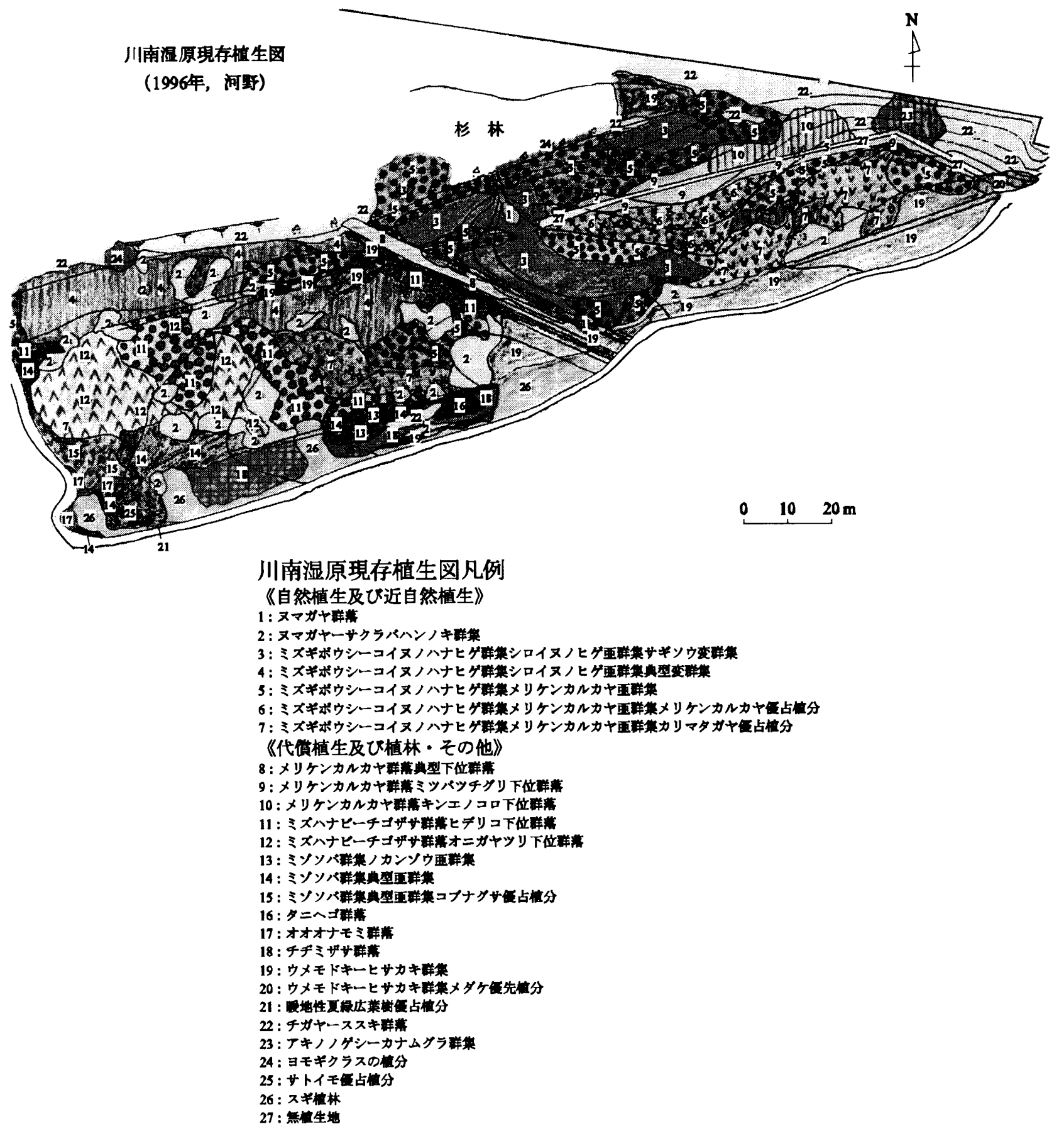

図 6: 川南湿原の湿原植物の分布状態 
ばならないと考えられる，具体的には，以下の対策を 講じる必要がある。

(i) ため池に隣接する病院からの処理水が湿原へ流 入しないように対策を講じること。すなわち、こ の対策の一つとして処理水を川南町の下水道へ 連結することが考えられる。

(ii）窒素やリンを多量に含むホテイアオイは冬場に 枯死しして，池の底に沈澱・堆積するが，これ を 30 年間余り放置しているので, 湿原上流部の ため池の浚渫を行い, 除去すること.

以上の対策を実施することにより，天然記念物の川南 湿原の保全は可能であると考えている. 現在，この対 策の実現を文部科学省文化庁と県の農村整備課に交涉 しているところである。そして，湿原の整備を行い，
湿原植物の保全と增殖を重ね，天然記念物を活用した 九州唯一の湿原公園を完成させる予定である.

\section{引用文献}

[1] 秋吉康弘・稲垣仁根 - 山村善洋 - 中園健文 (2002):天然 記念物川南湿原の保全に関する研究, 第 83 回農業土 木学会九州支部講演集, pp.145-148.

[2] 秋吉康弘 - 稲垣仁根 - 中園健文 - 小山田正幸 - 山村善 洋 (2003): 天然記念物湿原の保護について，日本雨水資 源化システム学会大会第 11 回研究発表会講演要旨集, pp.61-66.

[3] 川南町教育委員会 (1999a):川南湿原の自然環境－国指 定天然記念物川南湿原植物群落自然環境調査報告書一, pp.72-108.

[4] 川南町教育委員会 (1999b):川南湿原の自然環境一国指 定天然記念物川南湿原植物群落自然環境調査報告書一, pp.157-163.

(この論文に対する公開の質疑または討議は2004年12 